\title{
Characterization of a Phytoplasma Associated with Frogskin Disease in Cassava
}

\author{
Elizabeth Alvarez, Juan F. Mejía, Germán A. Llano, and John B. Loke, Plant Pathology Program, Tropical Fruit \\ Project, International Center for Tropical Agriculture (CIAT), Cali, Valle del Cauca, Colombia; Alberto Calari, \\ DiSTA, Patologia Vegetale, Alma Mater Studiorum, University of Bologna, Italy; Bojan Duduk, DiSTA, Patologia \\ Vegetale, Alma Mater Studiorum, University of Bologna, Italy and Institute of Pesticides and Environmental Protec- \\ tion, Belgrade, Serbia; and Assunta Bertaccini, DiSTA, Patologia Vegetale, Alma Mater Studiorum, University of \\ Bologna, Italy
}

\begin{abstract}
Alvarez, E., Mejía, J. F., Llano, G. A., Loke, J. B., Calari, A., Duduk, B., and Bertaccini, A. 2009. Characterization of a phytoplasma associated with frogskin disease in cassava. Plant Dis. 93:1139-1145.

Cassava frogskin disease (CFSD) is an economically important root disease of cassava (Manihot esculenta) in Colombia and other South American countries, including Brazil, Venezuela, Peru, Costa Rica, and Panama. The roots of severely affected plants are thin, making them unsuitable for consumption. In Colombia, phytoplasma infections were confirmed in 35 of 39 genotypes exhibiting mild or severe CFSD symptoms either by direct or nested polymerase chain reaction (PCR) assays employing ribosomal (r)RNA operon primer pairs. The CFSD-associated phytoplasmas were identified as group 16SrIII strains by restriction fragment length polymorphism (RFLP) and sequence analyses of amplified rDNA products, and results were corroborated by PCRs employing group 16SrIII-specific rRNA gene or ribosomal protein (rp) gene primers. Collectively, RFLP analyses indicated that CFSD strains differed from all phytoplasmas described previously in group $16 \mathrm{SrIII}$ and, on this basis, the strains were tentatively assigned to new ribosomal and ribosomal protein subgroups $16 \mathrm{SrIII}-\mathrm{L}$ and $\mathrm{rpIII}-\mathrm{H}$, respectively. This is the first molecular identification of a phytoplasma associated with CFSD in cassava in Colombia.
\end{abstract}

Cassava frogskin disease (CFSD) is an important disease affecting cassava (Manihot esculenta Crantz) roots, whose causal agent has remained unknown for many years despite its economic significance. Recently, it has been reported with increasing frequency in Colombia, Brazil, Venezuela, Peru, Costa Rica, and Panama, with an incidence of up to $90 \%$ recorded in Colombian commercial fields in the production areas of Valle del Cauca, Cauca, Meta, and the North Coast $(6,35)$. CFSD causes deep lesions in roots, eventually reducing their diameter; therefore, in many cassava cultivars, symptoms are observed only when the plants are harvested. Some cultivars may also show leaf symptoms such as mosaic, chlorosis, and curling or curvature in leaf margins. However, these symptoms are difficult to observe under field conditions, and could be confused

Corresponding author: E. Alvarez

E-mail: ealvarez@cgiar.org

Current address of E. Alvarez: CIAT, Km 17 recta Cali-Palmira, Valle del Cauca, Colombia, air mail 6713.

GenBank accession numbers AY737646, AY737647, and EU346761.

Accepted for publication 30 June 2009.

doi:10.1094/PDIS-93-11-1139

(C) 2009 The American Phytopathological Society with damage from mites, thrips, deficiencies of microelements, viruses (6), or herbicide toxicity, or they can be masked when temperatures are high $\left(>30^{\circ} \mathrm{C}\right)$. Characteristic CFSD symptoms in the roots are a woody aspect and a thickened peel that is cork-like, fragile, and opaque. The peel also presents lip-like slits that, when they join, create a net-like or honeycomb pattern. In advanced stages of the disease, the sclerenchyma and parenchyma are brown instead of white, cream, or pink. In many cases, roots may be very thin and the bases of stems very thick (7). When roots do not tuberize adequately, stems tend to be thicker than normal. Generally, the aerial parts of diseased plants are more vigorous and better developed than those of healthy plants. In contrast, the roots of healthy plants are well developed, with thin, shiny, and flexible peels.

In open fields, the disease may affect plants with different levels of symptom severity in the roots; other plants remain asymptomatic with a few characteristic slits, whether scattered or localized in the root. Depending on the intensity of symptoms in mother plants from which cuttings are produced, the severity and incidence of infected roots per plant increases from one planting cycle to another.

To develop appropriate management strategies for reducing the spread of this disease, a proper identification of possible etiological agent or agents is necessary.
Phytoplasmas have been recently detected in CFSD-affected cassava of susceptible commercial cultivars, using nested polymerase chain reaction (PCR) to amplify a fragment of the $16 \mathrm{~S}$ ribosomal (r)RNA gene, but were not detected in healthy plants from the same cultivars harvested from fields free of the disease (2).

Various diseases that induce symptoms in roots in diverse plant species have been reported to be associated with phytoplasmas $(8,14,26,33)$. The objectives of this study were to (i) show a close association of CFSD symptoms and the presence of phytoplasmas; (ii) identify and characterize phytoplasmas consistently associated with CFSD-affected roots, leaf midribs, petioles, and stems of different cassava cultivars and genotypes from various regions of Colombia; and (iii) verify transmissibility of phytoplasmas associated with frogskin disease to healthy cassava and periwinkle plants.

\section{MATERIALS AND METHODS}

Plant material. Symptomatic, 1-yearold cassava plants were collected from 2002 to 2004 from commercial plantations and the International Center for Tropical Agriculture (CIAT) collection in three areas of Colombia where CFSD has been endemic for more than 20 years (North Coast: $9^{\circ} 19^{\prime} 08 \mathrm{~N}, 75^{\circ} 17^{\prime} 46 \mathrm{~W}, 150 \mathrm{~m}$; Valle del Cauca: $3^{\circ} 30^{\prime} 03.51 \mathrm{~N}, 7^{\circ} 21^{\prime} 20.04 \mathrm{~W}$, $980 \mathrm{~m} ;$ and Cauca: $3^{\circ} 04^{\prime} 16.90 \mathrm{~N}$, $\left.76^{\circ} 29^{\prime} 57.34 \mathrm{~W}, 1,038 \mathrm{~m}\right)$. Leaf, midrib, petiole, stem, and root tissues from samples representing 39 genotypes of cassava grown in the field or in the greenhouse were collected. In all, 5 plants of each genotype (195 plants total) were sampled and their leaf, stem, and root tissues were pooled separately for PCR analyses (not all tissues were sampled from each genotype), giving a total of 76 samples (Table 1). The roots of all 195 plants selected for molecular analyses were examined for symptoms and classified according to a scale of symptom severity modified from Little et al. (29). The ratings were as follows: $0=$ no symptoms in roots and roots have a thin and flexible peel; $10=$ very mild symptoms, only a few fissures or lip-like splits in a limited number of roots; roots are slightly opaque with an inflexible peel; 35 $=$ mild symptoms, a few fissures or lip-like 
splits in many roots (roots have an opaque and brittle peel); 65 = moderate symptoms, many fissures or lip-like splits in all root parts, some reduction of root size (roots are opaque with a brittle peel); $90=$ severe symptoms, reticulations or honeycombing in several roots, moderate reduction of root diameter/volume (roots have a thick, corklike, and brittle peel); 100, very severe symptoms, reticulation or honeycombing in many roots with severe reduction of root mass (roots have a pronounced woody or fibrous character and a thick, cork-like and brittle peel) (Table 1). Samples from cassava plants obtained by meristem culture in vitro were employed as negative controls for PCR assays.

Table 1. Detection of phytoplasmas in cassava samples using nested polymerase chain reaction (PCR)

\begin{tabular}{|c|c|c|c|c|}
\hline \multirow[b]{2}{*}{ Rating (no.), genotypes ${ }^{b}$} & \multirow[b]{2}{*}{ Tissue $^{c}$} & \multicolumn{3}{|c|}{ PCR tests ${ }^{\mathbf{a}}$} \\
\hline & & $\mathbf{A}$ & B & $\mathbf{C}$ \\
\hline \multicolumn{5}{|l|}{$100(10)$} \\
\hline CM 6740-7 & Leaf & $4 / 6$ & $4 / 6$ & $6 / 6$ \\
\hline CM $849-1$ & Root & $3 / 4$ & $3 / 4$ & $4 / 4$ \\
\hline CM 5460-10 & Stem & nt & nt & nt \\
\hline M Col 2063 (CFSDY17) & $\ldots$ & $\ldots$ & $\ldots$ & $\ldots$ \\
\hline CM 9582-24 & $\ldots$ & $\ldots$ & $\ldots$ & $\ldots$ \\
\hline SM 1219-9 (CFSDY29) & $\ldots$ & $\ldots$ & $\ldots$ & $\ldots$ \\
\hline \multicolumn{5}{|l|}{$90(15)$} \\
\hline M Bra 383 & Leaf & $3 / 7$ & $5 / 7$ & $6 / 7$ \\
\hline Venezolana & Root & $4 / 8$ & $6 / 8$ & $7 / 8$ \\
\hline CM 9582-65 & Stem & $\mathrm{nt}$ & $\mathrm{nt}$ & nt \\
\hline ICA Nataima & $\ldots$ & $\ldots$ & $\ldots$ & $\ldots$ \\
\hline CM 9582-64 & $\ldots$ & $\ldots$ & $\ldots$ & $\ldots$ \\
\hline CG 6119-5 & $\ldots$ & $\ldots$ & $\ldots$ & $\ldots$ \\
\hline SM 909-25 (CFSDY15) & $\ldots$ & $\ldots$ & $\ldots$ & $\ldots$ \\
\hline \multicolumn{5}{|l|}{$65(14)$} \\
\hline M CR 81 & Leaf & $1 / 7$ & $5 / 7$ & $7 / 7$ \\
\hline M Col 634 & Root & $1 / 6$ & $4 / 6$ & $6 / 6$ \\
\hline M Per 16 & Stem & $0 / 1$ & $1 / 1$ & $1 / 1$ \\
\hline CM 3306-9 & $\ldots$ & $\ldots$ & $\ldots$ & $\ldots$ \\
\hline Manzana & $\ldots$ & $\ldots$ & $\ldots$ & $\ldots$ \\
\hline ICA Catumare & $\ldots$ & $\ldots$ & $\ldots$ & $\ldots$ \\
\hline CIAT Parrita & $\ldots$ & $\ldots$ & $\ldots$ & $\ldots$ \\
\hline \multicolumn{5}{|l|}{$35(8)$} \\
\hline CM 2177-1 & Leaf & $0 / 4$ & $3 / 4$ & $4 / 4$ \\
\hline HMC-1 & Root & $0 / 4$ & $2 / 4$ & $4 / 4$ \\
\hline M Per 335 & Stem & $\mathrm{nt}$ & $\mathrm{nt}$ & $\mathrm{nt}$ \\
\hline CM 3306-19 & $\ldots$ & $\ldots$ & $\ldots$ & $\ldots$ \\
\hline CM 4919-1 & $\ldots$ & $\ldots$ & $\ldots$ & $\ldots$ \\
\hline \multicolumn{5}{|l|}{$10(21)$} \\
\hline M Bra 856-54 & Leaf & $0 / 12$ & $1 / 12$ & $10 / 12$ \\
\hline M Bra 882 & Root & $0 / 9$ & $0 / 9$ & $9 / 9$ \\
\hline M Cub 74 & Stem & $\mathrm{nt}$ & $\mathrm{nt}$ & $\mathrm{nt}$ \\
\hline M Col 1468 & $\ldots$ & $\ldots$ & $\ldots$ & $\ldots$ \\
\hline M Col 1178 & $\ldots$ & $\ldots$ & $\ldots$ & $\ldots$ \\
\hline M Bra 325 & $\ldots$ & $\ldots$ & $\ldots$ & $\ldots$ \\
\hline M Bra 856 & $\ldots$ & $\ldots$ & $\ldots$ & $\ldots$ \\
\hline SM 1201-5 & $\ldots$ & $\ldots$ & $\ldots$ & $\ldots$ \\
\hline GM 228-14 & $\ldots$ & $\ldots$ & $\ldots$ & $\ldots$ \\
\hline M Bra 829 & $\ldots$ & $\ldots$ & $\ldots$ & $\ldots$ \\
\hline M Bra 839 & $\ldots$ & $\ldots$ & $\ldots$ & $\ldots$ \\
\hline \multicolumn{5}{|l|}{$0(8)$} \\
\hline M Chn 2 & Leaf & $0 / 4$ & $0 / 4$ & $0 / 4$ \\
\hline Manzana & Root & $0 / 4$ & $0 / 4$ & $0 / 4$ \\
\hline ICA Catumare & Stem & $\mathrm{nt}$ & $\mathrm{nt}$ & $\mathrm{nt}$ \\
\hline M Arg 2 & $\ldots$ & $\ldots$ & $\ldots$ & $\ldots$ \\
\hline
\end{tabular}

${ }^{\text {a Number of positive samples/total samples tested; } \mathrm{nt}=\text { not tested. } \mathrm{A}=\text { primers } \mathrm{P} 1 / \mathrm{P} 7 \text { and }}$ $\mathrm{P} 1 / \mathrm{P} 7+\mathrm{R} 16 \mathrm{~F} 2 \mathrm{n} / \mathrm{R} 16 \mathrm{R} 2, \mathrm{~B}=\mathrm{R} 16 \mathrm{mF} 2 / \mathrm{R} 16 \mathrm{mR} 1+\mathrm{R} 16 \mathrm{~F} 2 \mathrm{n} / \mathrm{R} 16 \mathrm{R} 2$, and $\mathrm{C}=\mathrm{R} 16 \mathrm{~F} 2 \mathrm{n} / \mathrm{R} 16 \mathrm{R} 2+$ R16(III)F2/R16(III)R1.

${ }^{\mathrm{b}}$ Disease rating (number of samples), and genotypes. Rating: $0=$ no symptoms, $10=$ very mild symptoms, $35=$ mild symptoms, $65=$ moderate symptoms, $90=$ severe symptoms, and $100=$ very severe symptoms.

${ }^{\mathrm{c}}$ Leaf indicates a mix of leaf blade, midrib and petiole tissue. variegatus from Italy (API), ranunculus virescence (RA), and clover yellow edge (CYE; C) (ribosomal subgroup B); golden rod yellows (GRI; ribosomal subgroup D); spirea stunt (SPI; ribosomal subgroup E); Vaccinium witches' broom (VAC) and milkweed yellows (MW1) (ribosomal subgroup F); walnut witches' broom (WWB; ribosomal subgroup $\mathrm{G}$ ); poinsettia branchinducing (JRI; ribosomal subgroup $\mathrm{H}$ ); Virginia grapevine yellows (VGY; ribosomal subgroup I); chayote witches' broom (ChWB; ribosomal subgroup J); strawberry leafy fruit (SLF; ribosomal group $\mathrm{K}$ ); dandelion virescence (DanVir; ribosomal subgroup P); black raspberry witches' broom (BRWB7; ribosomal subgroup Q); cirsium white leaf phytoplasma (CWL; ribosomal subgroup U); and Solanum marginatum big bud from Ecuador (SBB).

Nucleic acid extraction. DNA was extracted from $0.4 \mathrm{~g}$ of tissue from each plant part as described previously $(19,36)$. Tissue samples were frozen and ground in liquid nitrogen using a sterile mortar and pestle. After the final ethanol precipitation, nucleic acid extracts were resuspended in 30 to $50 \mu \mathrm{l}$ of Tris-EDTA (10 mM Tris$\mathrm{HCl}, \mathrm{pH} 8.0$, and $1 \mathrm{mM}$ EDTA, $\mathrm{pH}$ 8.0) buffer and stored at $4^{\circ} \mathrm{C}$ until use.

PCR amplification of phytoplasma DNA. Phytoplasma universal primer pair P1/P7 (11,38) was used to amplify DNA from the $16 \mathrm{~S}$ and the beginning of the $23 \mathrm{~S}$ rRNA genes, plus the spacer region between them, and primer pairs $\mathrm{R} 16 \mathrm{mF} 2 /$ $\mathrm{R} 16 \mathrm{mR} 1$ and R16F2n/R16R2 (20) were used to amplify part of the $16 \mathrm{~S}$ gene in either direct or nested-PCR assays. For nested PCR, the resulting P1/P7 and $\mathrm{R} 16 \mathrm{mF} 2 / \mathrm{R} 16 \mathrm{mR} 1$ amplicons from the direct PCR were diluted 1:29 with sterile high-performance liquid-chromatographygrade water and the second amplification was done with the R16F2n/R16R2 primer pair. Samples amplified directly with $\mathrm{R} 16 \mathrm{~F} 2 \mathrm{n} / \mathrm{R} 16 \mathrm{R} 2$ were diluted 1:50 with sterile water and then subjected to nested PCR with the 16SrIII group-specific primer pair R16(III)F2/R16(III)R1 (25). The DNA from plants infected with a coffee crispiness phytoplasma strain (CCP; AY525125) (18) was employed as a positive control, while DNAs from healthy cassava or sterile water were included as negative controls in each assay.

The amplifications were carried out as described previously $(27,32)$ with the primer pairs described above and those listed in Table 2. Each reaction was $25 \mu \mathrm{l}$, with $100 \mathrm{ng}$ of DNA, $1 \times$ buffer, $3 \mathrm{mM}$ $\mathrm{MgCl}_{2}, 1 \mathrm{U}$ of $\mathrm{Taq}$ polymerase (Promega Corp., Madison, WI), $0.8 \mathrm{mM}$ dNTPs (Invitrogen Life Technologies, Carlsbad, CA), and $0.1 \mu \mathrm{M}$ each primer (Operon Technologies, Inc., Alameda, CA). The amplified products were analyzed by electrophoresis in a $1.5 \%$ agarose gel, visualized by staining with ethidium bromide at 0.75 $\mu \mathrm{g} / \mathrm{ml}$, and imaged with a Stratagene Eagle 
Eye II video system (Stratagene, La Jolla, CA).

Further molecular characterization of CFSD DNA extracts was performed by direct PCR and nested-PCR amplification of a 300-bp fragment of the 16SrIII group ribosomal protein operon (10) using the primer pair rpL2F3/rp(I)R1A (31) for the first amplification, followed by the nested primer pair rpIIIF1/rpIIIR1. This PCR was performed using the conditions described by Schaff et al. (37) (Table 2, footnote) and amplicons were visualized as described above.

RFLP analysis of PCR products. For identification of the phytoplasmas associated with CFSD, the direct and nested PCR products were subjected to RFLP analysis. R16(III)F2/R16(III)R1-derived amplicons were digested with $R s a \mathrm{I}, A l u \mathrm{I}, M s e \mathrm{I}$, and TaqI restriction endonucleases (New England Biolabs, Beverly, MA) whereas P1/P7 and R16F2n/R16R2 amplicons were digested with HpaII, TruI, and HhaI (Fermentas, Vilnius, Lithuania) following the instructions of the manufacturer. The nested-PCR amplicons obtained with the rpIIIF1/rpIIIR1 primers were analyzed with restriction enzymes TruI, AluI (Fermentas), and Tsp509I (New England Biolabs). Separation of bands generated from restriction digests was performed in 5\% polyacrylamide gels and staining and visualization of DNA was as described above for agarose gels.

Multiple alignments of 16S rRNA sequences were made with CLUSTALX (40) using GenBank sequences of selected phytoplasma strains (CYE, WWB, VGY, ChWB, SLF, DanVir phytoplasma, and BRWB7 phytoplasmas) which represented different 16 SrIII subgroups. These alignments were used to generate putative restriction site maps with the DNASTAR program MapDraw option (DNASTAR Inc.). These maps were manually aligned for comparison with virtual patterns obtained from the P1/P7 amplicon sequence (EU346761), covering the entire 16SrDNA and spacer region between 16SrDNA and 23SrDNA, of phytoplasma strain CFSDY15 DNA digested with endonucleases HpaII, MseI, HhaI, and Sau3AI.

Sequencing of PCR products. R16F2n/ R16R2 amplicons from samples CFSDY17 and CFSDY29 (Table 1) were purified using a Qiaquick PCR Purification Kit (Qiagen GmbH, Hilden, Germany) and cloned in vector pGEM-T Easy and Escherichia coli DH5 $\alpha$ cells (Invitrogen Life Technologies). Two clones per sample of the 1,200 - to 1,300 -bp insert were fully sequenced in both directions (Iowa State University, Office of Biotechnology, Ames). The R16F2n/R16R2 PCR products amplified from samples CFSDY17 and CFSDY29 also were sequenced directly after purification with a DNA-sequencing kit from Applied Biosystems. Sequences were edited and assembled using Se- quencher 4.1 software (Gene Codes Corp., Ann Arbor, MI).

Direct sequencing in both directions using primers P1, F1 (9), and P7 was also performed on the P1/P7 amplicon from sample CFSDY15 after processing with a QIAquick PCR Purification Kit (Qiagen $\mathrm{GmbH})$. The sequences were assembled using Sequencher 4.1 software and compared with selected nucleotide sequences in the GenBank database using BLAST (version Blast N 2.2.18) at the National Center for Biotechnology Information, Bethesda, MD.

Cladistic analysis of CFSD phytoplasma sequences. Publicly available 16S rDNA sequences from 43 representative strains of the genus 'Candidatus Phytoplasma' (23), including strains belonging to different subgroups of the 16SrIII group, were retrieved from GenBank and aligned with the 16S ribosomal DNA sequences from CFSDY15, CFSDY17, and CFSDY29 using CLUSTALX and BioEdit (21). Phytoplasma strains employed for cladistic analyses, belonging to $16 \mathrm{Sr}$ groups different than 16SrIII, were ' $\mathrm{Ca}$. P. asteris' (M30790), 16SrI; 'Ca. P. aurantifolia' (U15442), 16SrII; Tanzanian coconut lethal decline (X80117), 16SrIV; ' $C a$. P. ulmi' (AF122910), 'Ca. P. ziziphi' (AF305240), and flavescence dorée (X76560), 16SrV; 'Ca. P. trifolii' (AY390261), 16SrVI; 'Ca. P. fraxini' (AF092209), 16SrVII; Loofah witches' broom (AF086621), 16SrVIII; 'Ca. P. phoenicium' (AF515637), 16SrIX; 'Ca. P. mali' (AJ542541), 'Ca. P. prunorum' (AJ542544), 'Ca. P. pyri' (AJ542543), 'Ca. P. spartii' (X92869), and 'Ca. P. rhamni' (X76431), 16SrX; stolbur (AF248959) and ' $C a$. P. australiense' (L76865), 16SrXII; Mexican periwinkle virescence (AF248960), 16SrXIII; 'Ca. P. cynodontis' (AJ550984), 16SrXIV; 'Ca. P. brasiliense' (AF147708), 16SrXV; 'Ca. P. graminis' (AY725228), 16SrXVI; 'Ca. P. caricae' (AY723254), 16SrXVII; and ' $C a$. P. americanum' (DQ174122) 16SrXVIII.

Before constructing phylogenetic trees, all sequences were trimmed to consist of only 16 SrDNA. Phylogenetic trees were constructed with maximum parsimony (MP) analysis using the close neighbor interchange algorithm, with the initial tree created by random addition for 10 replica- tions. Neighbor-joining (NJ) and minimum evolution (ME) using nucleotide p-distances were performed with MEGA version 4 (39). For all methods, bootstrap analysis was also performed and replicated 500 times for estimation of stability and support for the clades; the complete deletion option was used for gaps in all analyses. Acholeplasma laidlawii (a cultivable Mollicute) is phylogenetically related to phytoplasmas and was designated as the outgroup to root the trees.

Phytoplasma transmission by grafting and dodder. Transmission experiments were carried out in an insect-proof greenhouse at 20 to $25^{\circ} \mathrm{C}$ and 50 to $90 \%$ relative humidity (RH) using naturally infected potted cassava plants as sources of inoculum. Infected donor plants were of the cassava genotype SM909-25, which showed severe symptoms in roots and leaf chlorosis and curling under greenhouse conditions $\left(23^{\circ} \mathrm{C}\right.$ and $\left.80 \% \mathrm{RH}\right)$, and the genotype CW94-21 from the CW family in CIAT's cassava genetic improvement program, which showed mild disease symptoms under field conditions.

Transmission using dodder plants grown from seed germinated in an insect-proof greenhouse was performed for about 2 months from a single CFSD symptomatic source plant of each indicated cassava genotype to six 2-month-old cassava plantlets obtained from in vitro culture and to six 5- to 6-week-old periwinkle seedlings per trial. The plants were visually inspected every week for 3 months for the appearance of symptoms.

Graft transmission using leaf midribs, petioles, and shoots from each of five infected SM 909-25 and CW 94-21 cassava plants via cleft, chip-budding, and spliced whip-grafts to six cassava and periwinkle plants per cultivar was also done using donor samples selected for stem diameters similar to those of recipient plants. Graft unions were carefully covered with Parafilm and a plastic bag for 1 to 3 weeks. Plants were incubated in the greenhouse and observed for symptom development for 5 months as described above.

The presence and identity of phytoplasmas was assessed in all the plants before and after transmission experiments using nested-PCR assays with R16F2n/R16R2 primers followed by nested primers

Table 2. Primer combinations employed for polymerase chain reaction (PCR) analyses of phytoplasmas infecting cassava

\begin{tabular}{llll}
\hline PCR system $^{\mathbf{a}}$ & \multicolumn{1}{c}{ Direct PCR } & \multicolumn{1}{c}{ Nested PCR } & \multicolumn{1}{c}{ Sequences amplified } \\
\hline $\mathrm{A}$ & $\mathrm{P} 1 / \mathrm{P} 7$ & $\mathrm{R} 16 \mathrm{~F} 2 \mathrm{n} / \mathrm{R} 16 \mathrm{R} 2$ & 16Sr RNA \\
$\mathrm{B}$ & $\mathrm{R} 16 \mathrm{mF} 2 / \mathrm{R} 16 \mathrm{mR} 1$ & $\mathrm{R} 16 \mathrm{~F} 2 \mathrm{n} / \mathrm{R} 16 \mathrm{R} 2$ & 16Sr RNA \\
$\mathrm{C}$ & R16F2n/R16R2 & R16(III)F2/R16(III)R1 & 16Sr RNA \\
$\mathrm{D}$ & $\mathrm{P} 1 / \mathrm{P} 7$ & - & 16Sr-5' of 23S RNA \\
E & rpL2F3/rp(I)R1A & rpIIIF1/rpIIIR1 & Ribosomal protein operon (rp gene) \\
\hline
\end{tabular}

${ }^{\mathrm{a}}$ For each system, denaturation was $2 \mathrm{~min}$ at $94^{\circ} \mathrm{C}$ for the first cycle and $1 \mathrm{~min}$ for each additional cycle; 35 cycles for systems A, B, C, and D and 40 cycles for E. Annealing was 2 min at $55^{\circ} \mathrm{C}$ for A and $\mathrm{B}$, and $50^{\circ} \mathrm{C}$ for $\mathrm{C}, \mathrm{D}$, and $\mathrm{E}$; primer extension was at $72^{\circ} \mathrm{C}$ for 3 min for each cycle except for the final cycle at $10 \mathrm{~min}$. 
R16(III)F2/R16(III)R1. For positive samples, the RFLP analyses or the sequencing methods described above were applied for phytoplasma identification.

\section{RESULTS}

RFLP analyses of PCR products. Direct $\mathrm{PCR}$ with $\mathrm{P} 1 / \mathrm{P} 7$ primers and nested PCR with R16F2n/R16R2 or R16(III)F2/ $\mathrm{R} 16$ (III)R1 primers resulted in the amplification of 1.7-, 1.2-, and 0.8-kb DNA fragments, respectively, from the majority of symptomatic cassava plants. The P1/P7 primer pair alone yielded direct amplification only from the SM 1219-9 and SM 909-25 cassava genotypes, which were infected with the CSFDY29 and CFSDY15 strains, respectively (data not shown). Nested-PCR protocols detected phytoplasmas in the 25 cassava genotypes that exhibited symptoms of CFSD, with a disease rating of 35 to 100 (Table 1 ). Within rating group 10, no phytoplasma was detected in genotypes SM 1201-5 and GM 228-14 by any PCR assay, whereas samples from the other 12 genotypes in this rating group were positive for phytoplasma (Table 1).
Genotypes MChn2, ICA Catumare, Manzana, and $\mathrm{M} \mathrm{Arg} 2$ that are in rating group 0 were asymptomatic and negative for phytoplasmas (Table 1). Negative control samples of cassava from in vitro culture were always negative in all direct and nestedPCR assays employed (data not presented).

PCR with the nested primer pair R16(III)F2/R16(III)R1 (Table 1, C) amplified the expected fragment from $97 \%$ $(30 / 31)$ of root samples and $92 \%(33 / 36)$ of leaf samples from plants with symptom ratings between 10 and 100 (Table 1 ). The other two nested-PCR assays (Table 1, A and B) were comparatively less effective in phytoplasma detection, with detection of phytoplasma in $22 \%(8 / 36)$ and $26 \%$ (8/31) of leaf and root samples, respectively, using system $\mathrm{A}$ and detection in $50 \%(18 / 36)$ and $48 \%(15 / 31)$ of leaf and root samples, respectively, using system B.

RFLP analysis of the products obtained with the R16(III)F2/R16(III)R1 primers showed that all of the cassava samples tested and the control strain CCP yielded mutually indistinguishable RFLP patterns with the RsaI, AluI, MseI, and TaqI restriction enzymes (data not shown). RFLP patterns of P1/P7 and R16F2n/R16R2 amplicons obtained from the CFSD samples listed in Table 1 showed identical profiles (data not shown); therefore, only RFLP data from sample CFSDY15 (obtained from cassava genotype SM 909-25) is presented. Collectively, digestion profiles of P1/P7 and R16F2n/R16R2 amplicons generated with restriction enzymes HpaII, TruI, and HhaI distinguished CFSDY15 from the indicated phytoplasma reference strains (Fig. 1A and B). The HpaII restriction enzyme profile of the P1/P7 amplicon distinguished CFSDY15 from all other phytoplasma strains employed (Fig. 1A), whereas the HpaII, TruI, and HhaI profiles of the R16F2n/R16R2 amplicon were indistinguishable from several other phytoplasmas (Fig. 1B). The results of virtual restriction site analysis of the $16 \mathrm{~S}$ ribosomal gene from strain CSFDY15 agreed with the RFLP analysis results in polyacrylamide gels, indicating that this strain is distinguishable from CYE, DanVir phytoplasma, and BRWB7

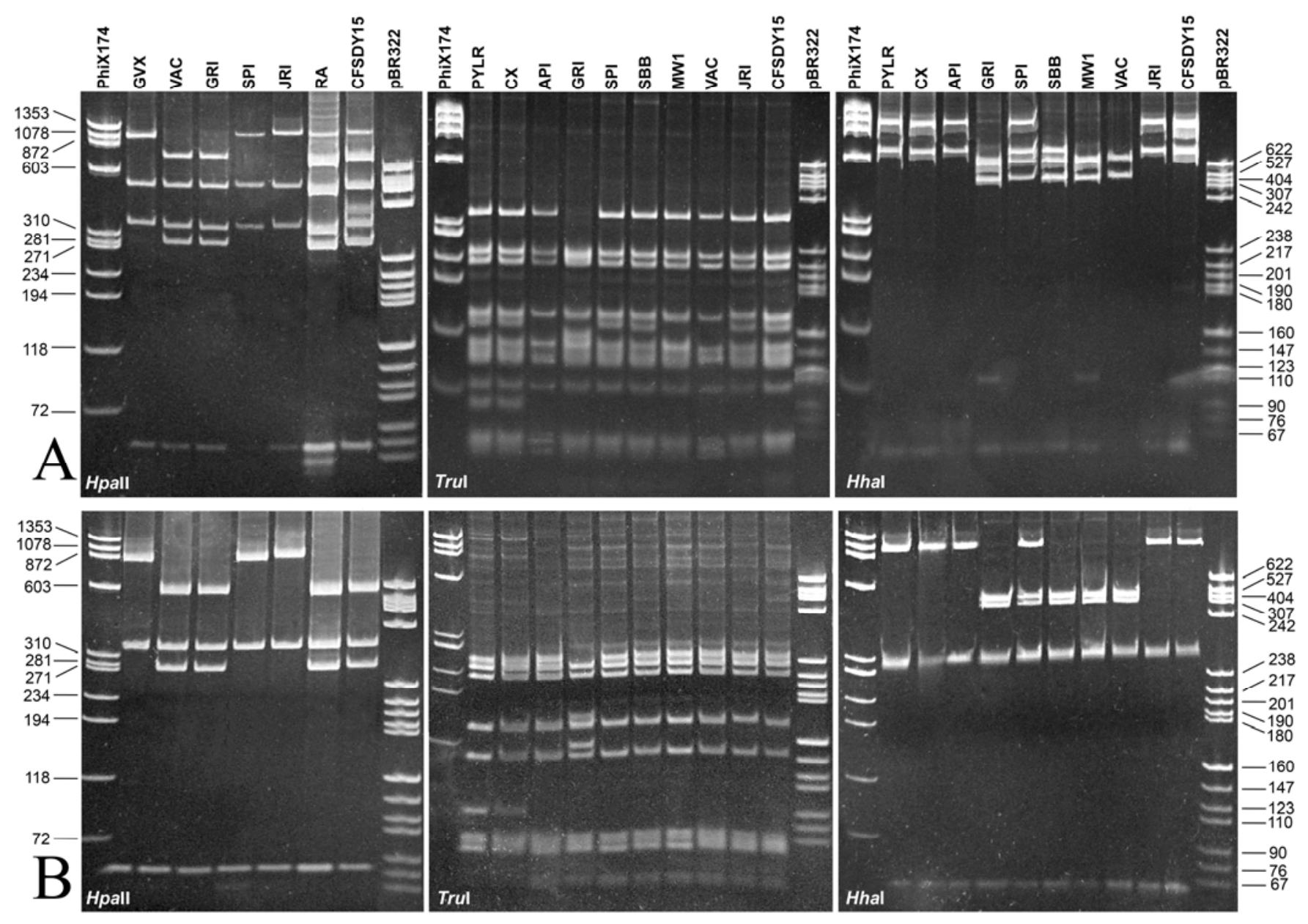

Fig. 1. Polyacrylamide gels showing the restriction fragment length polymorphism profiles of 16S rDNA amplified in direct polymerase chain reaction (PCR) with A, primers P1/P7 and $\mathbf{B}$, in nested PCR with primers R16F2n/R16R2 from representative phytoplasma strains and from cassava frogskin disease phytoplasma strain CFSDY15. The three gels (left to right) in both panels A and B show banding patterns resulting from HpaII, TruI, and HhaI restriction endonuclease digests. Phytoplasma strains used for reference digestion patterns: GVX, Green Valley X disease; VAC, Vaccinium witches' broom; GRI, golden rod yellows; SPI, spirea stunt; JRI, poinsettia branch-inducing; RA, ranunculus virescence; PYLR, peach yellowleaf roll; CX, peach X-disease; API, phytoplasma from Euscelidius variegatus from Italy; SBB, Solanum marginatum big bud from Ecuador; and MWI, milkweed yellows. Left and right outer lanes contain PhiX174, marker ФX174 HaeIII-digested PhiX174 and HaeI digested pBR322 marker DNAs, respectively. 
strains by the absence of an MseI (TruI) site in position 1,524. The CFSDY15 strain lacks a Sau3AI site and shows an HpaII site at about positions 200 and 800, respectively, when compared with WWB and VGY sequences; it lacks also an HhaI site that is present in ChWB, SLF, DanVir phytoplasma, and BRWB7 at positions 550 and 750. The results of RFLP and virtual RFLP analyses clearly indicate that phytoplasma infecting cassava differs on $16 \mathrm{Sr}$ RNA from all others described (data not presented), and could be assigned to a new 16SrIII-L subgroup.

Nested PCR using the ribosomal protein group-III-specific primers (Table 2) produced amplicons of the expected size from CFSDY15-infected symptomatic cassava samples (leaf and roots) and also from selected phytoplasma reference strains belonging to the $16 \mathrm{SrIII}$ group (data not shown). RFLP analyses of this amplicon with $A l u \mathrm{I}$ restriction enzyme showed no differences between cassava strain CFSDY15 and most of the reference strains employed; however, its TruI and Tsp509I profiles were unique, indicating that phytoplasmas infecting cassava could be assigned to a new ribosomal protein subgroup, rpIII-H (Fig. 2).

Cladistic analyses. Sequencing of the R16F2n/R16R2 amplicons of strains CFSDY17 and CFSDY29 and of the P1/P7 amplicon from CFSDY15 yielded sequences of 1,260, 1,298 (amplicons were sequenced directly and variable sequence quality led to editing to yield sequences of different lengths even though the original amplicons were of equivalent sizes), and 1,679 bp, respectively, which were deposited in GenBank with the accession numbers AY737646, AY737647, and EU346761.

MP analysis of the 16S rRNA gene of CFSD phytoplasmas CFSDY15, CFSDY17, and CFSDY29 strains and 43 representative strains of the genus 'Candidatus Phytoplasma' grouped CFSD phytoplasma with phytoplasmas belonging to $16 \mathrm{SrIII}$ group. Cladistic analysis of 16S rRNA nucleotide sequences by $\mathrm{NJ}, \mathrm{ME}$, and MP methods provided trees with similar topology; therefore, the MP results are shown (Fig. 3). CFSD isolates CFSDY17, CFSDY29, and CFSDY15 clustered together as part of a larger cluster composed of members of the 16SrIII group, and their placement in the tree suggests they are closely related to ChWB and CWL phytoplasmas, which belong to the 16SrIII-J and 16SrIII-U ribosomal subgroups, respectively. The bootstrap support for the proposed new ribosomal subgroup 16SrIII-L within the $16 \mathrm{SrIII}$ group was $67 \%$ in the MP tree and 67 and $65 \%$ in the NJ- and ME-generated trees, respectively (data not shown).

Transmission of CFSD phytoplasma. No specific symptoms were observed in cassava or periwinkle receptor plants inoculated with either transmission method. Based on results from nested-PCR assays, graft transmission occurred in five of six transmissions from infected source SM 909-25 to both periwinkle and cassava, and from source CW 94-21 in four of six and three of six transmissions to cassava and periwinkle, respectively. Dodder transmission occurred only from cv. SM 909-25, with one of six and two of six transmissions successful to cassava and periwinkle respectively (Table 3 ). The identity of phytoplasmas in the receptor plants was confirmed as CFSD phytoplasma by sequencing or RFLP assays (data not shown). These phytoplasmas were indistinguishable from those of the donor plants and from those identified in the samples from symptomatic cassava.

\section{DISCUSSION}

In this study, the presence of a phytoplasma in tissues of plants exhibiting symptoms of CFSD was confirmed by direct- and nested-PCR assays for two phytoplasma genes. RFLP analyses of the
16S rRNA, intergenic spacer sequences, and ribosomal protein gene sequences indicated that the phytoplasmas infecting cassava belong to a new ribosomal DNA and ribosomal protein subgroups which are proposed to be named 16SrIII-L and rpIII-H, respectively (28)

The cladistic analysis of the $16 \mathrm{~S}$ rRNA gene confirmed that the 16SrIII ribosomal group is highly supported while the branch support for the newly named 16SrIII-L subgroup within the larger 16SrIII group is considerably weaker. Nevertheless, results supporting creation of 16 SrIII-B, -F, -G, $-\mathrm{H},-\mathrm{I},-\mathrm{J},-\mathrm{K},-\mathrm{Q},-\mathrm{P}$, and $-\mathrm{U}$ subgroups already reported in the literature $(9,24,28,32)$ had less bootstrap support than the newly proposed 16 SrIII-L subgroup. Other studies have shown that the subgrouping system using the 16Sr RNA gene does not have adequate branch support to have significant phylogenetic meaning but it was shown, however, to have geographic and strain relevance (28). Phytoplasmas belonging to the 16SrIII group have been reported in chinaberry (Melia azedarach) in Bolivia; in chayote showing witches' broom disease and tomato showing big bud disease in Brazil; in garlic (Allium sativum L.) and in chinaberry $(3,17,22)$ in Argentina; and, finally, in association with several diseases, including cassava witches' broom in Brazil (5). The detection of closely related phytoplasmas in many crops in South America suggests the presence and wide distribution of specific insect vectors or dissemination via propagation material into these different environments.

In cassava plants, phytoplasmas were detected with direct PCR amplification only in petioles and midribs of young leaves. Successful detection in roots required a nested-PCR assay. The best sensitivity was obtained with nested PCR, employing the primer pairs $\mathrm{R} 16 \mathrm{~F} 2 \mathrm{n} / \mathrm{R} 16 \mathrm{R} 2$ followed by group 16SrIII-specific primers. This system

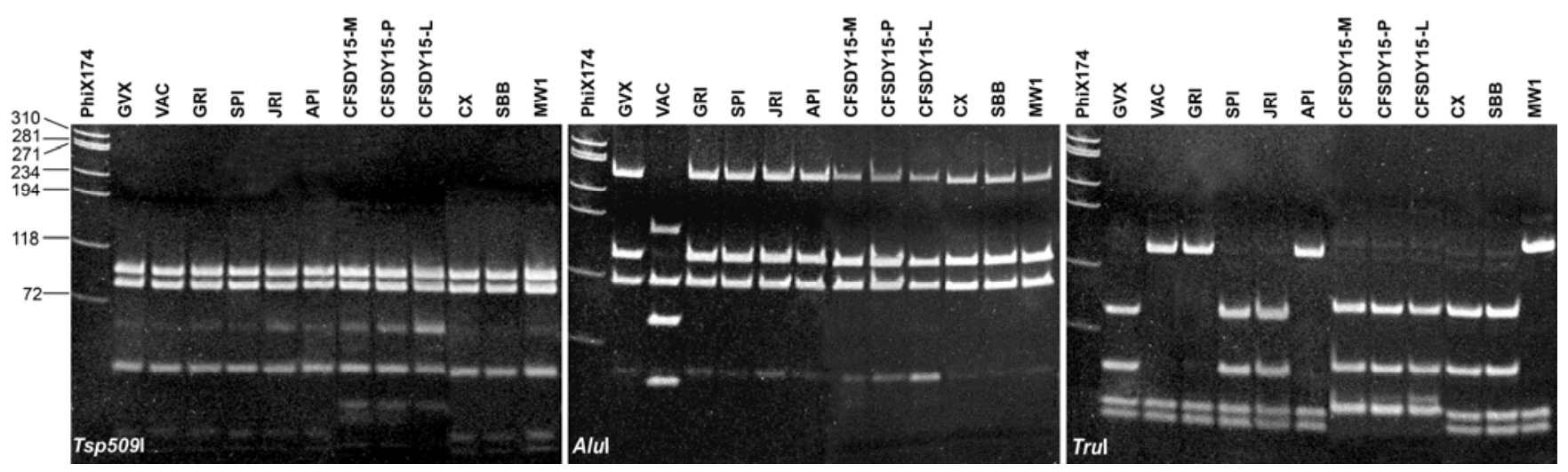

Fig. 2. Polyacrylamide gels showing restriction fragment length polymorphism patterns of phytoplasma DNAs from cassava and selected reference strains amplified in nested polymerase chain reaction with the rpIIIF1/rpIIIR1 primer pair. The three gels (left to right) show Tsp509I, AluI, and TruI restriction endonuclease digests. Lanes marked CFSDY15-M, -P, and -L contain digested DNA amplified separately from midribs (M), petioles (P), and leaves (L) infected with cassava frogskin disease phytoplasma strain CFSDY15. Phytoplasma strains (left to right) used for reference digestion patterns: GVX, Green Valley X disease; VAC, Vaccinium witches' broom; GRI, golden rod yellows; SPI, spirea stunt; JRI, poinsettia branch-inducing; API, phytoplasma from Euscelidius variegatus from Italy; CX, peach X-disease; SBB, Solanum marginatum big bud from Ecuador; MW1, milkweed yellows. Outermost left lane in each gel contains HaeIII-digested PhiX174 marker DNA. 
(Table 1, C) produced 97 and $92 \%$ of positive result among the symptomatic root and leaf samples, respectively. The lack of pathogen detection in a few plants phenotypically evaluated as diseased but with very mild symptoms (rating 10) could be related to the uneven distribution of phytoplasmas in planta, as already reported for other species (15).

The lack of specific symptoms in cassava and periwinkle plants infected through dodder or grafting under greenhouse conditions is consistent with our observations that limited symptoms develop on naturally infected greenhousegrown cassava plants, and may be related to the short period of symptom observation (up to 5 months).
Although Koch's postulates cannot be fulfilled for nonculturable phytoplasmas, the association of a phytoplasma with the majority of symptomatic cassava plants suggests that it is likely the causal agent of CFSD. Moreover, the CFSD root symp-

Table 3. Results of phytoplasma transmission by grafting and dodder from infected cassava to healthy cassava and periwinkle

\begin{tabular}{lcc}
\hline & \multicolumn{2}{c}{ Results from indicated donor sources $^{\mathbf{a}}$} \\
\cline { 2 - 3 } Transmission & SM 909-25 & CW 94-21 \\
\hline Dodder transmission to healthy cassava & $1 / 6$ & $0 / 6$ \\
Dodder transmission to healthy periwinkle & $2 / 6$ & $0 / 6$ \\
Grafting to healthy cassava & $5 / 6$ & $4 / 6$ \\
Grafting to healthy periwinkle & $5 / 6$ & $3 / 6$ \\
\hline
\end{tabular}

a Number of plants in which phytoplasmas were detected/number of receptor plants employed for transmission experiment.

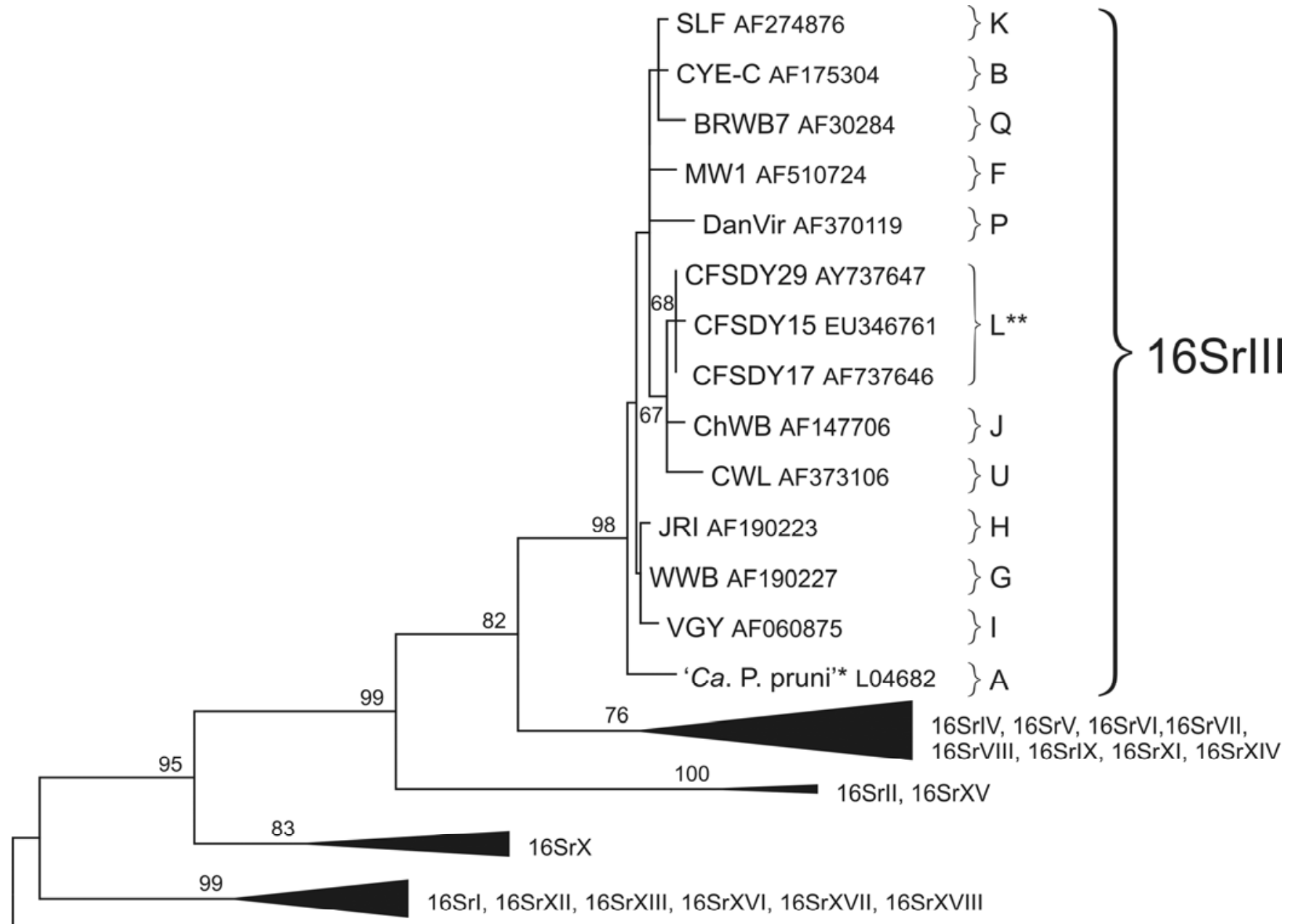

\section{A. laidlawii M23932}

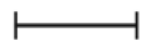

10

Fig. 3. Phylogenetic tree constructed by maximum parsimony analysis of near-full-length 16S rDNA sequences from phytoplasma strains CFSDY15, CFSDY17, and CFSDY29 from Colombia and from reference phytoplasmas within the genus 'Candidatus Phytoplasma'. Acronyms of strains in the 16SrIII group: SLF, strawberry leafy fruit; CYE-C, clover yellow edge; BRWB7, black raspberry witches' broom; MW1, milkweed yellows; DanVir, dandelion virescence; ChWB, chayote witches' broom; CWL, cirsium white leaf phytoplasma; JRI, poinsettia branch-inducing; WWB, walnut witches' broom; VGY, Virginia grapevine yellows; 'Ca. P. pruni', 'Candidatus Phytoplasma pruni'. Numbers after phytoplasma acronyms are GenBank accession numbers. Triangles indicate clusters of sequences representative of at least one member of each of the indicated 16S subgroups (23,27). Scale bar indicates the number of substitutions per site. Asterisks: $*={ }^{*} \mathrm{Ca}$. P. pruni': this name was proposed at the X International Congress of the International Organization of Mycoplasmology, Bordeaux, France, 1994, but is not yet formally described. The name is reported here as an incidental citation which does not constitute prior citation, according to rule $28 \mathrm{~b}$ of the bacteriological code (25); ** = subgroup suggested in this article. 
potato infected by phytoplasmas and showing sweet potato little leaf disease, symptoms include stunting of the whole plant, and roots are also visibly affected. Depending on the time of infection, cassava tuber yields can also be severely affected and plants infected at early growing stages may not produce harvestable tubers (8). Similarly, observations from other studies indicate that carrot phytoplasmas induce, among other symptoms, a reduction in the size and quality of taproots $(13,26,33)$.

Several diseases reported as being of viral etiology were later associated with phytoplasma infection $(12,30)$ and, in some cases, both viruses and phytoplasmas were found to be associated with diseases $(1,4,16)$. The reported detection of viruses in CFSD-affected plants $(6,7)$ cannot exclude the possibility that additional pathogens can affect symptom expression. More work on the epidemiology of CFSD and on the genetic susceptibility of cassava genotypes to this disease is in progress.

\section{ACKNOWLEDGMENTS}

We thank the unknown reviewers and the senior editor for their help in editing and improving the presentation of the work performed.

\section{LITERATURE CITED}

1. Aljanabi, S. M., Parmessur, Y., Moutia, Y., Saumtally, S., and Dookun, A. 2001. Further evidence of the association of a phytoplasma and a virus with yellow leaf syndrome in sugarcane. Plant Pathol. 50(5):628-636.

2. Alvarez, E., Mejía, J. F., Loke, J. B., Hernández, L., and Llano, G. A. 2003. Detecting the phytoplasma-frogskin disease association in cassava (Manihot esculenta Crantz) in Colombia. (Abstr.) Phytopathology 93:S4.

3. Arneodo, J. D., Marini, D. C., Galdeano, E., Meneguzzi, N., Bacci J. R., Domecq, C., Nome, S. F., and Conci, L. R. 2007. Diversity and geographical distribution of phytoplasmas infecting China-tree in Argentina. J. Phytopathol. 155:70-75

4. Arocha, Y., Peralta, E. L., and Jones, P. 2001. Molecular characterization of phytoplasmas associated with sugarcane yellow leaf syndrome (YLS) in Cuba. Caribbean Division Meeting Abstracts. Publication no. P-2002-0006-CRA.

5. Barros, T., Kitajima, E. W., and Resende, R. O. 1998. Diversidade de isolados brasileiro de fitoplasmas através da análise do $16 \mathrm{~S}$ rDNA. Fitopatol. Bras. 23(4):459-465.

6. Calvert, L. A., Cuervo, M., Lozano, I., Villareal, N., and Arroyave, J. 2004. Identification of a reolike virus infecting Manihot esculenta and associated with cassava frog-skin disease. Sixth Int. Sci. Meet. Cassava Biotechnol. Network. PS4:68.

7. Chaparro-Martinez, E. I., and Trujillo-Pinto, G. 2001. First report of frog skin disease in cassava (Manihot esculenta) in Venezuela. Plant Dis. 85:1285.

8. Crossley, S. J., and Clark, M. F. 1996. A plate capture PCR method for epidemiological studies with sweet potato little leaf and other phytoplasma diseases. Brighton Crop Prot. Conf. Pests Dis. 2:18-21.

9. Davis, R. E., Jomantiene, R., Dally, E. L., and Wolf, T. K. 1998. Phytoplasmas associated with grapevine yellows in Virginia belong to group 16SrI, subgroup A (tomato big bud phytoplasma subgroup), and group 16SrIII, new subgroup I. Vitis 37(3):131-137.
10. Davis, R. E., and Lee, I.-M. 1993. Clusterspecific polymerase chain reaction amplification of 16S rDNA sequences for detection and identification of mycoplasmalike organisms. Phytopathology 83:1008-1001.

11. Deng, S., and Hiruki, C. 1991. Amplification of 16S rRNA genes from culturable and nonculturable mollicutes. J. Microbiol. Methods 14:53-61.

12. Doi, Y., Teranaka, M., Yora, K., and Asuyama, H. 1967. Mycoplasma or PLT-group-like microorganisms found in the phloem elements of plants infected with mulberry dwarf, potato witches' broom, aster yellows, or paulownia witches' broom. Ann. Phytopathol. Soc. Jpn. 33:259-266.

13. Duduk, B., Bulajić, A., Duduk, N., Calari, A., Paltrinieri, S., Kristić, B., and Bertaccini, A. 2007. Identification of phytoplasmas belonging to aster yellows ribosomal group (16SrI) in vegetables in Serbia. Bull. Insectol. 60:341-342.

14. Dyer, A. T., and Sinclair, W. A. 1991. Root necrosis and histological changes in surviving roots of white ash infected with mycoplasmalike organisms. Plant Dis. 75:814-819.

15. EPPO/CABI (European and Mediterranean Plant Protection Organization and CAB International). 1996. Apple proliferation phytoplasma. In: Quarantine Pests for Europe, 2nd ed. I M Smith, D. G. McNamara, P. R. Scott, and $\mathrm{M}$ Holderness, eds. CAB International, Wallingford, UK

16. Fránová, J., Paltrinieri, S., Botti, S., Šimková, M., and Bertaccini, A. 2004. Association of phytoplasmas and viruses with malformed clovers. Folia Microbiol. 49(5):617-624.

17. Galdeano, E., Torres, L. E., Meneguzzi, N., Guzmán, F., Gomez, G. G., Docampo, D. M., and Conci, L. R. 2004. Molecular characterization of $16 \mathrm{~S}$ ribosomal DNA and phylogenetic analysis of two X-diseases group phytoplasma affecting China-tree (Melia azedarach L.) and garlic (Allium sativum L.) in Argentina. J. Phytopathol. 152:174-181.

18. Galvis, C. A., Leguizamón, J. E., Gaitán, A. L., Mejía, J. F., Alvarez, E., and Arroyave, J. 2007. Detection and identification of a group 16SrIII-related phytoplasma associated with coffee crispiness disease in Colombia. Plant Dis. 91:248-252.

19. Gilbertson, L., and Dellaporta, S. L. 1983. Molecular extraction DNA protocols. Pages 395-397 in: Molecular Biology of Plants. Cold Spring Harbor Laboratory, Cold Spring Harbor, NY.

20. Gundersen, D. E., and Lee, I-M. 1996. Ultrasensitive detection of phytoplasma by nestedPCR assays using two universal primer pairs. Phytopathol. Mediterr. 35:114-151.

21. Hall, T. A. 1999. Bio Edit: a user-friendly biological sequence alignment editor and analysis program for Windows 95/98/NT. Nucleic Acids Symp. Ser. 41:95-98.

22. Harrison, N. A., Boa, E., and Carpio, M. L. 2003. Characterization of phytoplasmas detected in Chinaberry trees with symptoms of leaf yellowing and decline in Bolivia. Plant Pathol. 52:147-157.

23. IRPCM 2004. 'Candidatus Phytoplasma', a taxon for the wall-less, non-helical prokaryotes that colonize plant phloem and insects. Int. J. Syst. Evol. Microbiol. 54:1243-1255.

24. Jomantiene, R., Davis, R. E., Valiunas, D., and Alminaite, A. 2002. New group 16SrIII phytoplasma lineages in Lithuania exhibit rRNA interoperon sequence heterogeneity. Eur. J. Plant Pathol. 108:507-517.

25. Lapage S. P., Sneath P. H. A., Lessel E. F., Skerman V. B. D., Seeliger H. P. R., and Clarck W. A. 1992. International Code of Nomenclature of Bacteria: Bacteriological Code, 1990 Revision. American Society of Microbi- ology, Washington, DC

26. Lee, I.-M., Bottner, K. D., Munyaneza, J. E., Davis, R. E., Crosslin, J. M. du Toit, L. J., and Crosby, Z. 2006. Carrot purple leaf: A new spiroplasmal disease associated with carrots in Washington State. Plant Dis. 90:989-993.

27. Lee, I.-M., Gundersen, D. E., Hammond, R. W., and Davis, R. E. 1994. Use of mycoplasmalike organism (MLO) group-specific oligonucleotide primers for nested-PCR assays to detect mixed-MLO infections in a single host plant. Phytopathology 84:559-566.

28. Lee, I.-M., Gundersen-Rindal, D. E., Davis, R. E., and Bartoszyk, I.M. 1998. Revised classification scheme of phytoplasma based on RFLP analyses of 16SrRNA and ribosomal protein gene sequences. Int. J. Syst. Bacteriol. 48:11531169

29. Little, T. M., and Hills, F. J. 1978. Agricultural Experimentation: Design and Analysis. John Wiley and Sons, New York.

30. Liu, B., White, D. T., Walsh, K. B., and Scott, P. T. 1996. Detection of phytoplasma in dieback, yellow crinkle, and mosaic diseases of papaya using polymerase chain reaction techniques. Aust. J. Agric. Res. 47(3):387-394.

31. Martini, M., Lee, I.-M., Bottner, K. D., Zhao, Y., Botti, S., Bertaccini, A., Harrison, N. A., Carraro, L., Marcone, C., Khan, A. J., and Osler, R. 2007. Ribosomal protein gene-based phylogeny for finer differentiation and classification of phytoplasmas. Int. J. Syst. Bacteriol. 57:2037-2051.

32. Montano, H. G., Davis, R. E., Dally, E. L., Pimentel, J. P., and Brioso, P. S. T. 2000. Identification and phylogenetic analysis of a new phytoplasma from diseased chayote in Brazil. Plant Dis. 84:429-436.

33. Orenstein, S., Franck, A., Kuznetzova, L., Sela, I., and Tanne, E. 1999. Association of phytoplasmas with a yellows disease of carrot in Israel. J. Plant Pathol. 81(3):193-199.

34. Pilkington, L. J., Gibb, K. S., Gurr, G. M., Fletcher, M. J., Nikandrow, A., Elliott, E., van de Ven, R., and Read, D. M. Y. 2003. Detection and identification of a phytoplasma from lucerne with Australian lucerne yellows disease. Plant Pathol. 52:754-762.

35. Pineda, B., Jayasinghe, U., and Lozano, J. C. 1983. La enfermedad "Cuero de Sapo" en yuca (Manihot esculenta Crantz). ASIAVA 4:10-12.

36. Prince, J. P., Davis, R. E., Wolf, T. K., Lee, IM., Mogen, B., Dally, E., Bertaccini, A., Credi, R., and Barba, M. 1993. Molecular detection of diverse mycoplasmalike organisms (MLOs) associated with grapevine yellows and their classification with aster yellows, X-disease, and elm yellows MLOs. Phytopathology 8310:1130-1137.

37. Schaff, D. A., Lee, I.-M., and Davis, R. E. 1992. Sensitive detection and identification of mycoplasmalike organisms by polymerase chain reactions. Biochem. Biophys. Res. Commun. 186:1503-1509.

38. Smart, C. D., Schneider, B., Blomquist, C. L., Guerra, L. J., Harrison, N. A., Ahrens, U., Lorenz, K. H., Seemuller, E., and Kirkpatrick, B. C. 1996. Phytoplasma-specific PCR primers based on sequences of the 16S-23S rRNA spacer region. Appl. Environ. Microbiol. 62:2988-2993.

39. Tamura, K., Dudley, J., Nei. M., and Kumar, S. 2007. MEGA4: Molecular Evolutionary Genetics Analysis (MEGA) software version 4.0. Mol. Biol. Evol. 24:1596-1599.

40. Thompson, J. D., Gibson, T. J., Plewniak, F., Jeanmougin, F., and Higgins, D. G. 1997. The Clustal X windows interface: flexible strategies for multiple sequence alignment aided by quality analysis tools. Nucleic Acids Res. 24:4876-4882. 